\title{
Limiting Populations and Spread of Clavibacter michiganensis subsp. michiganensis on Seedling Tomatoes in the Greenhouse
}

\author{
N. A. Werner, Former Graduate Assistant, and D. W. Fulbright, Professor, Department of Plant Pathology, Michi- \\ gan State University, East Lansing 48824-1312; R. Podolsky, Assistant Professor, Department of Biology, Univer- \\ sity of Michigan-Flint, Flint 48502; J. Bell, Visiting Research Associate, and M. K. Hausbeck, Associate Profes- \\ sor, Department of Plant Pathology, Michigan State University, East Lansing 48824-1312
}

\begin{abstract}
Werner, N. A., Fulbright, D. W., Podolsky, R., Bell, J., and Hausbeck, M. K. 2002. Limiting populations and spread of Clavibacter michiganensis subsp. michiganensis on seedling tomatoes in the greenhouse. Plant Dis. 86:535-542.

Symptomless greenhouse tomato transplants may harbor high populations of Clavibacter michiganensis subsp. michiganensis, the causal agent of bacterial canker, leading to yield loss in the field. The objective of this study was to determine whether resistant cultivars, acibenzolar- $S$ methyl, avirulent strains of $C$. michiganensis subsp. michiganensis, or standard bactericides reduce pathogen populations and spread among greenhouse tomato seedlings. All treatments limited pathogen populations compared with the untreated inoculated susceptible cultivar in 1996 and 1998, but not in 1997. In 1996, copper hydroxide alone or mixed with mancozeb or streptomycin limited pathogen populations relative to acibenzolar- $S$-methyl, acibenzolar- $S$ methyl mixed with copper hydroxide, and avirulent strains. Copper hydroxide mixed with streptomycin limited pathogen populations compared with copper hydroxide mixed with mancozeb. Adding copper hydroxide to acibenzolar-S-methyl limited pathogen populations compared with acibenzolar-S-methyl alone. In 1998, treatments did not differ significantly from each other in limiting pathogen populations. The treatments limited spread of the bacterium only in 1997. Copper hydroxide mixed with mancozeb limited spread compared with copper hydroxide mixed with streptomycin. Pathogen spread was also reduced among resistant cultivars compared with the susceptible cultivar treated with streptomycin. In the field, the untreated inoculated susceptible cultivar produced yields that were 61\% (1996) and 93\% (1997) of those produced by the uninoculated susceptible cultivar. Fruit spotting occurred regardless of treatment. To prevent severe bacterial canker disease in the field, growers should initiate and sustain bactericide applications to tomato transplants while in the greenhouse to suppress pathogen populations. Cultivar resistance and acibenzolar- $S$-methyl may be helpful in disease management of bacterial canker on tomato.
\end{abstract}

Additional keywords: bacterial canker

In the Midwest, tomato transplants are grown in local greenhouses for use in establishing production fields. Greenhouse transplants can appear to be healthy, yet harbor high populations of Clavibacter michiganensis subsp. michiganensis, the causal agent of bacterial canker, that may lead to severe disease symptoms in the field (11). Infection by C. michiganensis subsp. michiganensis can result in plant wilting, stunting, reduced yields, and plant death. Less severe disease symptoms include marginal leaf necrosis that may be bordered by chlorosis, and fruit lesions that appear as superficial white spots (3 to 6 $\mathrm{mm}$ ) that develop a necrotic center.

Applications of copper bactericides to

Corresponding author: M. K. Hausbeck

E-mail: hausbec1@msu.edu

Accepted for publication 7 January 2002.

Publication no. D-2002-0304-04R

(C) 2002 The American Phytopathological Society transplants in the greenhouse can limit $C$. michiganensis subsp. michiganensis population size and spread and subsequently decrease yield loss (11). The pathogen population must be suppressed below $10^{7}$ $\mathrm{CFU} / \mathrm{g}$ of tissue at the time of transplanting to prevent yield loss in the field (11). There are few strategies to manage bacterial canker after symptoms appear in the field, but growers can apply copper bactericides.

Long-term and continuous use of copper bactericides may lead to copper resistant bacteria (4). While resistance to copper has not been noted for Clavibacter spp. (4), a disease management program that is not wholly reliant on copper bactericides is desirable. Novel products for management of bacterial diseases include those that activate systemic acquired resistance (SAR) in plants (10) such as acibenzolar-Smethyl (ABM; Actigard 50WDG, Syngenta Crop Protection, Inc., Greensboro, NC) $(13,22)$. Tomato cultivars moderately resistant to bacterial canker have also been developed that exhibit reduced foliar blight and yield losses compared with susceptible cultivars (19). The application of avirulent strains of bacterial pathogens may provide another management option. In 1994, avirulent mutants of Pseudomonas solanacearum (causal agent of bacterial wilt in tomato) were able to colonize host tissue, and when plants were challenged with virulent strains, disease symptoms were reduced (7). The objective of this study was to compare the effectiveness of different management schemes, including the use of resistant cultivars, ABM, and avirulent strains of $C$. michiganensis subsp. michiganensis along with standard bactericides, in reducing pathogen populations and spread among greenhouse tomato seedlings. Populations of $C$. michiganensis subsp. michiganensis in the field and resulting yields were also determined.

\section{MATERIALS AND METHODS}

Culture of virulent and avirulent strains. The virulent strain of $C$. michiganensis subsp. michiganensis used was a rifampicin-resistant mutant of a reppolymerase chain reaction (PCR) fingerprint type B strain isolated in 1987 from tomato fruit from a farm in northeastern Ohio (14). The spontaneous rifampicinresistant mutation was selected by plating cells from a nutrient broth yeast extract (NBY) broth culture modified by omitting glucose (MNBY) (14) and adding $50 \mu \mathrm{g}$ of rifampicin per $\mathrm{ml}$. The strain was tested for pathogenicity to tomato by clipping the petioles of 10- to 14-day-old seedlings (cultivar H8704; H. J. Heinz Co., Pittsburgh, PA) with scissors dipped in a suspension of the bacterium that had been grown in MNBY broth, centrifuged at $1,564 \times g$ for $10 \mathrm{~min}$ at room temperature in a GSA rotor in a Sorvall RC5C centrifuge (DuPont Co., Wilmington, DE), resuspended in sterile distilled water, and adjusted spectrophotometrically to approximately $1 \times 10^{8} \mathrm{CFU} / \mathrm{ml}$. This strain consistently caused severe disease symptoms including stunting, wilting, and death of inoculated plants. The pathogen was reisolated from the inoculated plants and found to be rifampicin-resistant with an identical BOX-PCR fingerprint to the original inoculum.

The avirulent strains of $C$. michiganensis subsp. michiganensis were streptomycin-resistant mutants of BOX-PCR DNA fingerprint type A (14). Strain 40 was iso- 
lated from fresh market tomato stem tissue in 1988, and strain 302 was isolated from a lesion on a processing tomato fruit in 1994. Both samples were obtained from southeastern Michigan. The spontaneous streptomycin-resistant mutants (40S and 302S) were selected by plating cells from MNBY broth culture on MNBY containing $50 \mu \mathrm{g}$ of streptomycin per $\mathrm{ml}$. These strains were tested for pathogenicity as previously described, and symptoms were not observed. The strains were reisolated from the inoculated plants and found to be streptomycinresistant with identical BOX-PCR fingerprints to the original inoculum.

The virulent strain of $C$. michiganensis subsp. michiganensis used in the greenhouse experiments was prepared by inoculating two 5-ml broth culture tubes of MNBY containing $100 \mu \mathrm{g}$ of rifampicin per $\mathrm{ml}$ and incubating them for $48 \mathrm{~h}$ at room temperature on a shaker operating at $190 \mathrm{rpm}$. These cultures were used to inoculate 1 liter of MNBY containing $100 \mu \mathrm{g}$ of rifampicin per $\mathrm{ml}$. The culture was incubated for $48 \mathrm{~h}$ at $25^{\circ} \mathrm{C}$ on a shaker operating at $75 \mathrm{rpm}$, centrifuged, and the resulting pellets were resuspended in sterile distilled water to a final volume of 1 liter. The final bacterial concentration was approximately $1 \times 10^{8} \mathrm{CFU} / \mathrm{ml}$. The avirulent strains of $C$. michiganensis subsp. michiganensis were prepared as described above, except MNBY broth contained 100 $\mu \mathrm{g}$ of streptomycin per ml. The bacterial suspensions were kept on ice and applied as described below within $3 \mathrm{~h}$ of preparation.

Experimental design and treatments. On 13 and 14 May 1996, 24 March 1997, and 23 March 1998, plastic plug sheets $(52.5 \times 26.5 \times 4.0 \mathrm{~cm})$ each containing 288 cells filled with soilless medium were individually seeded with the susceptible
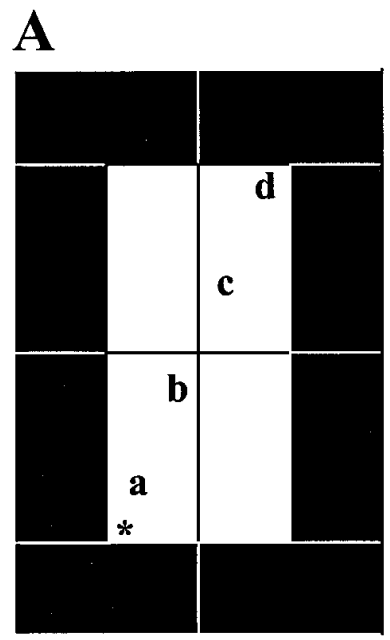

tomato cultivars H8704 (H. J. Heinz Co., Pittsburgh, PA; 1996, 1997) and Mountain Spring (Novartis Seeds, Inc., Gilroy, CA; 1998) and the resistant cultivars H9144 and H70214 (H. J. Heinz Co.; 1996, 1997) and germinated for 3 days in a walk-in germination chamber in a commercial greenhouse in southwestern Michigan. Plug sheets were then transported to a commercial polyethylene greenhouse (approximately $12.2 \times 29.3 \mathrm{~m}$ ) in Stockbridge, MI, and placed on overturned plastic flats on the earthen greenhouse floor covered with a black woven polyethylene groundcover. Seedlings were watered overhead as required, and irrigated biweekly with 100- or 200-ppm fertilizer solution (Peter's 20-1020; Grace-Sierra Horticultural Products Co., Milpitas, CA) beginning 1 month after seeding. Average maximum and minimum greenhouse temperatures were $25.9^{\circ} \mathrm{C}$ (day) and $11.6^{\circ} \mathrm{C}$ (night), respectively. The average relative humidity was $95.4 \%$.

The study was arranged in a randomized complete block design. Each treatment replicate consisted of 12 plug sheets (1996, 1997) or 15 plug sheets (1998) arranged as shown in Figure 1. Within each treatment, the inner four $(2 \times 2)$ plug sheets $(1996$, 1997), and the inner six $(2 \times 3)$ plug sheets (1998) were targeted for treatment, with the surrounding flats serving as buffers between treatments (Fig. 1). There were four replicates per treatment. Thiophanatemethyl (Cleary's 3336F, $0.72 \mathrm{ml}$ a.i./liter; Cleary Chemical, Dayton, NJ), chlorothalonil (Bravo Ultrex, $1.7 \mathrm{~kg}$ a.i./ha; Syngenta), chloronitrobenzene (Terraclor 400, $0.38 \mathrm{ml}$ a.i./liter; Uniroyal Chemical, Middlebury, CT), and triadimefon (Bayleton 50DF, $1.5 \mathrm{~g}$ a.i./liter; Bayer Corporation, Kansas City, MO) were applied as needed to manage nontarget pathogens including Botrytis cinerea (1997, 1998), Alternaria

\section{B}

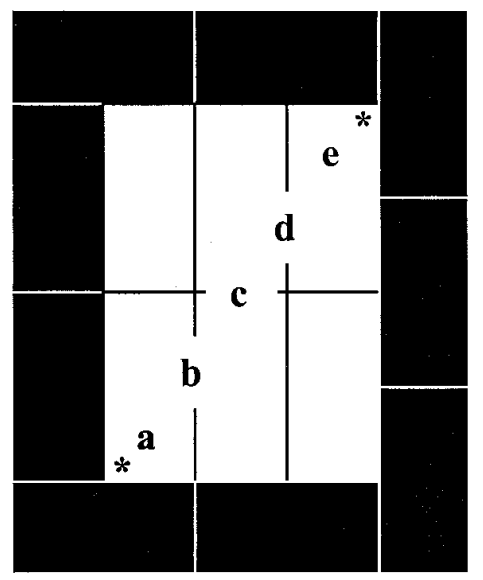

Fig. 1. Diagrams of a treatment with each rectangle representing a $52.5 \times 26.5 \mathrm{~cm}$ tray containing 288 tomato seedlings and solid areas serving as a buffer between treatments. A, In 1996 and 1997, seedlings were sampled from each treatment following the diagonal (sites a to d) from the Clavibacter michiganensis subsp. michiganensis inoculum focus (*). B, In 1998, seedlings were sampled from each treatment following the diagonal (sites a to e) between the C. michiganensis subsp. michiganensis inoculum foci (*). solani (1998), Sclerotinia sclerotiorum (1998), and Oidiopsis sicula (1998), respectively.

The following treatments were investigated on plants inoculated with $C$. michiganensis subsp. michiganensis: (i) copper hydroxide (Kocide 40DF, 3.0 g a.i./liter; Griffin LLC, Valdosta, GA); (ii) copper hydroxide (Kocide 40DF, 3.0 g a.i./liter) mixed with mancozeb (Dithane F-45, $2.9 \mathrm{~g}$ a.i./liter; Rohm and Haas Co., Philadelphia, PA); (iii) copper hydroxide (Kocide 40DF, $3.0 \mathrm{~g}$ a.i./liter) mixed with streptomycin (Agri-mycin 17, $0.25 \mathrm{~g}$ a.i./liter; Syngenta) (1996 and 1997 only); (iv) SAR-inducing compound ABM (Actigard 50WDG, 0.1 g a.i./liter; Syngenta); (v) ABM (Actigard 50WDG, 0.1 g a.i./liter) mixed with copper hydroxide (Kocide 40DF, 3.0 g a.i./liter) (1996 only); (vi) resistant cultivar H70214 (1996 and 1997 only); (vii) resistant cultivar H9144 (1996 and 1997 only); (viii) avirulent streptomycin-resistant strain of $C$. michiganensis subsp. michiganensis strain 302S (1996 and 1997 only); (ix) avirulent streptomycin-resistant $C$. michiganensis subsp. michiganensis strain 40S (1996 and 1997 only); (x) streptomycin (Agri-mycin 17, $0.25 \mathrm{~g}$ a.i./liter) (1997 and 1998 only); and (xi) untreated. Spray applications were applied only to susceptible cultivars. Additional treatments included untreated, uninoculated susceptible (all years) and resistant (1996 and 1997 only) cultivars. In each year, untreated, uninoculated plants of each cultivar were grown in a separate greenhouse under environmental and cultural conditions similar to those of the inoculated treatments to avoid contamination from inoculated plants.

Sprays of fungicides, ABM, antibiotic and avirulent strains of $C$. michiganensis subsp. michiganensis were applied using a $\mathrm{CO}_{2}$ backpack sprayer with two flat-fan 8002 spray tips (Teejet, Chicago) that were operated at $2.8 \mathrm{~kg} / \mathrm{cm}^{2}$ delivering approximately 748 liter/ha. Sprays were initiated when the first true leaves of the seedlings were visible and 1 to 2 days prior to the introduction of seedlings inoculated with the virulent rifampicin-resistant strain of $C$. michiganensis subsp. michiganensis. Sprays were applied every 5 days (10 June to 5 July 1996; 22 April to 17 May 1997; 25 April to 4 June 1998) until the seedlings were removed from the greenhouse and planted in the field.

Inoculation. On 11 June 1996, 23 April 1997, and 25 April 1998, seedlings of the susceptible cultivar were inoculated by misting the leaves with a virulent rifampicin-resistant suspension of C. michiganensis subsp. michiganensis (prepared as described above) using a Preval pressurized sprayer (Precision Valve Corporation, Yonkers, NY). The first true leaf of each individual seedling was then removed by clipping the petiole close to the stem with scissors dipped in the same suspension of 
C. michiganensis subsp. michiganensis. Inoculated seedlings were incubated overnight $(1996,1997)$ or for 2 days (1998) on a laboratory bench in loosely closed plastic bags to maintain high humidity. To initiate infection in the commercial greenhouse, 16 seedlings with their soilless plugs and roots intact were removed from one corner $(1996,1997)$ or from the two opposite corners (1998) of each treatment and replaced with the same number of inoculated seedlings to establish an inoculum focus $\left(^{*}\right)$ (* in Fig. 1).

Detection of $C$. michiganensis subsp. michiganensis on greenhouse seedlings. At 28 days (1996), 29 days (1997), and 42 days (1998) after inoculation, five to eight seedlings were removed from four sites (a to d; 1996, 1997) or five sites (a to e; 1998) within each treatment along the diagonal from the inoculum focus $(*)$ (* in Fig. 1). The inoculated plants used to initiate disease within each treatment were not included in the foliar samples. Each group of five to eight seedlings from each site was stored separately in plastic bags in a cooler at $4^{\circ} \mathrm{C}$ for a maximum of 3 days. Shoots and leaves of each plant were chopped with a sterile single-edged razor blade, weighed, and homogenized for $2 \mathrm{~min}$ in a Lab-Blender 400 stomacher (Tekmar Co., Cincinnati, $\mathrm{OH}$ ) with sterile phosphate buffer $(0.05 \mathrm{M}, \mathrm{pH} 7.4 ; 2 \mathrm{ml} / \mathrm{g}$ of plant tissue) amended with Tween-20 detergent $(0.02 \%)$. One $\mathrm{ml}$ of the plant extract was mixed with $0.5 \mathrm{ml}$ of $40 \%$ glycerol $(\mathrm{vol} / \mathrm{vol})$ and the resulting suspension stored at $-20^{\circ} \mathrm{C}$ (5) until further processing within a 6-month period.

Each sample was thawed on ice, and populations of the virulent pathogen were estimated from 10-fold serial dilutions spread on MNBY agar containing $100 \mu \mathrm{g}$ of rifampicin per $\mathrm{ml}$. Colonies were counted after 4 to 7 days. The lower limit of detection was $30 \mathrm{CFU} / \mathrm{g}$ of fresh tissue. A representative number of bacterial colonies from each year was chosen for BOXPCR DNA fingerprinting and verified as the same fingerprint type as the inoculum.

To determine if the untreated, uninoculated susceptible plants had been contaminated with the inoculum, 6 to 8 seedlings were arbitrarily removed from each cultivar $(1996,1997)$ or from each of the four flats (1998). Serially diluted homogenates were plated on MNBY agar containing 100 $\mu \mathrm{g}$ of rifampicin per ml. Colonies resembling C. michiganensis subsp. michiganensis were not recovered in any year.

Statistical analysis of greenhouse populations. Population data were analyzed by ANOVA as a completely randomized split-plot design with treatments as main plots and sites within treatments as subplots. The 1996 and 1997 data were transformed using $Y=\log _{10}(\mathrm{CFU}+1)$ to achieve normality, as determined by analyzing residuals using Proc Univariate (SAS Institute, Cary, NC). The assumption of equality of variances was examined using Levene's test (23). Because the variances in 1998 were not equal, an ANOVA of ranked population sizes was conducted (3) (Proc Rank and Proc GLM [SAS Institute]). This analysis is similar to other nonparametric procedures for less complex designs (3). Although the analysis is affected by unequal variances, this effect should be minimal compared with a parametric analysis. The following linear model was used for all ANOVA procedures: mean population of C. michiganensis subsp. michiganensis + treatment + site + treatment $\times$ site + block nested within treatment + error. Block nested within treatment was used as the error term for treatment.

Linear contrasts were used to examine the differences among treatments in bacterial populations and spread of bacterial populations within each treatment. The following contrasts were used to examine the differences in treatments for 1996: (i) untreated, inoculated susceptible cultivar versus all other treatments; (ii) inoculated resistant cultivars versus all other treatments; (iii) copper hydroxide alone or mixed with streptomycin or mancozeb versus $\mathrm{ABM}, \mathrm{ABM}$ mixed with copper hydroxide, and avirulent strain treatments; (iv) copper hydroxide alone versus copper hydroxide mixed with streptomycin or mancozeb; (v) copper hydroxide mixed with streptomycin versus copper hydroxide mixed with mancozeb; (vi) ABM versus ABM mixed with copper hydroxide (1996 only); (vii) ABM, ABM mixed with copper hydroxide versus avirulent strain treatments; (viii) avirulent strain $40 \mathrm{~S}$ versus avirulent strain 302S. In 1997, the effects of treatment on the spread of bacterial populations within each treatment (interaction of treatment and position) were examined using contrasts similar to those for 1996, with the following exceptions. ABM mixed with copper hydroxide was not a treatment in 1997, and the streptomycin treatment was included as a positive control. Streptomycin is considered to provide optimal control but is not registered for commercial use.

The following contrasts were used to examine the differences among treatments for 1998: (i) untreated, inoculated susceptible cultivar versus all other treatments; (ii) copper hydroxide alone or mixed with mancozeb versus untreated, inoculated susceptible cultivar; (iii) copper hydroxide versus copper hydroxide mixed with mancozeb; (iv) ABM versus untreated, inoculated susceptible cultivar; (v) streptomycin versus untreated, inoculated susceptible cultivar; (vi) copper hydroxide versus $\mathrm{ABM}$ and streptomycin; (vii) $\mathrm{ABM}$ versus streptomycin. Because these contrasts were not independent, and not entirely a priori comparisons, Bonferonni's correction was used to adjust $\alpha$ to $0.008(0.05 / 6)$; only contrasts with a $P$ value less than 0.008 were considered significant.
Field study. On 16 and 17 July 1996 and 28 May 1997, 48 seedlings were arbitrarily selected from the center (Fig. 1, sites $b$ and c) of each treatment and planted in a randomized complete block design with four replications at the Plant Pathology Research Farm, East Lansing, MI. The 1998 field plot is not included in this paper because additional treatments were applied in the field that were not included in 1996 and 1997. Field replicates were planted with the corresponding greenhouse replicate plants. The soil was a sandy loam in 1996 and a clay loam in 1997. The fields had been previously planted to sweet corn (1996) or rye (1997). Each treatment plot consisted of 12 seedlings planted into each of three 3.6-m-long rows spaced $1.5 \mathrm{~m}$ apart with $30.5 \mathrm{~cm}$ between plants within rows. The experimental sites were fertilized and weeds were managed according to standard commercial practices.

To prevent spread of the pathogen from nearby inoculated plants, uninoculated susceptible and resistant plants were sprayed with streptomycin (Agri-mycin 17, $0.187 \mathrm{~kg}$ a.i./ha) weekly using a pneumatic hand sprayer with a single spray tip operated at $2.8 \mathrm{~kg} / \mathrm{cm}^{2}$ delivering 748 liters $/ \mathrm{ha}$. All treatments were sprayed as needed, using the same method as described above, with the fungicide chlorothalonil (Bravo Weather Stik, $2.5 \mathrm{~kg}$ a.i./ha; Syngenta) to prevent fungal diseases.

Field sampling of fruit and foliage. On 2 October 1996 and 8 September 1997, plant stand counts were recorded for the middle 3.6-m-long row, and total yield and incidence of fruit spotting were recorded in a single harvest from the five innermost plants of the middle row. Foliage from plants was sampled on 26 September 1996 and 4 September 1997 from five or six plants in the center row of each treatment plot and processed as previously described to determine the pathogen populations. To verify that the field isolates were identical to the one used to inoculate the seedlings in the greenhouse, 44 (1996) colonies resembling C. michiganensis subsp. michiganensis were chosen for BOX-PCR DNA fingerprinting. Twenty-one colonies were rifampicin-resistant B types, 3 were rifampicin-resistant $C$ types, and 20 were not the pathogen.

Statistical analysis of field measurements. The 1996 and 1997 field data were analyzed as a randomized complete block design. Total fruit weight was transformed using $Y=(X+1)^{1 / 2}$. The transformed data were normally distributed with equal variances. Stand count data were not normally distributed, the variances were not equal, and the data could not be transformed to meet these assumptions. Therefore, ranks of stand count data were used in all subsequent analyses. The following contrasts were used to examine the differences among treatments for fruit weight and stand data in 1996: (i) untreated, inoculated 
susceptible and resistant cultivars versus untreated, uninoculated susceptible and resistant cultivars; (ii) untreated, inoculated and uninoculated susceptible cultivar versus all other treatments; (iii) inoculated and uninoculated resistant cultivars versus all other treatments; (iv) untreated, inoculated susceptible cultivar versus fungicides, ABM, ABM mixed with copper hydroxide, and avirulent strain treatments; (v) untreated, uninoculated susceptible cultivar versus fungicides, ABM, ABM mixed with copper hydroxide, and avirulent strain treatments; (vi) inoculated resistant cultivars versus fungicides, $\mathrm{ABM}, \mathrm{ABM}$ mixed with copper hydroxide, and avirulent strain treatments; (vii) uninoculated resistant cultivars versus fungicides, ABM, ABM mixed with copper hydroxide, and avirulent strain treatments; (viii) the interaction between inoculation and no inoculation; (ix) copper hydroxide alone or mixed with streptomycin or mancozeb versus ABM, $\mathrm{ABM}$ mixed with copper hydroxide, and avirulent strain treatments; (x) ABM and $\mathrm{ABM}$ mixed with copper hydroxide versus avirulent strain treatments; (xi) copper hydroxide versus copper hydroxide mixed with streptomycin or mancozeb; (xii) copper hydroxide mixed with streptomycin
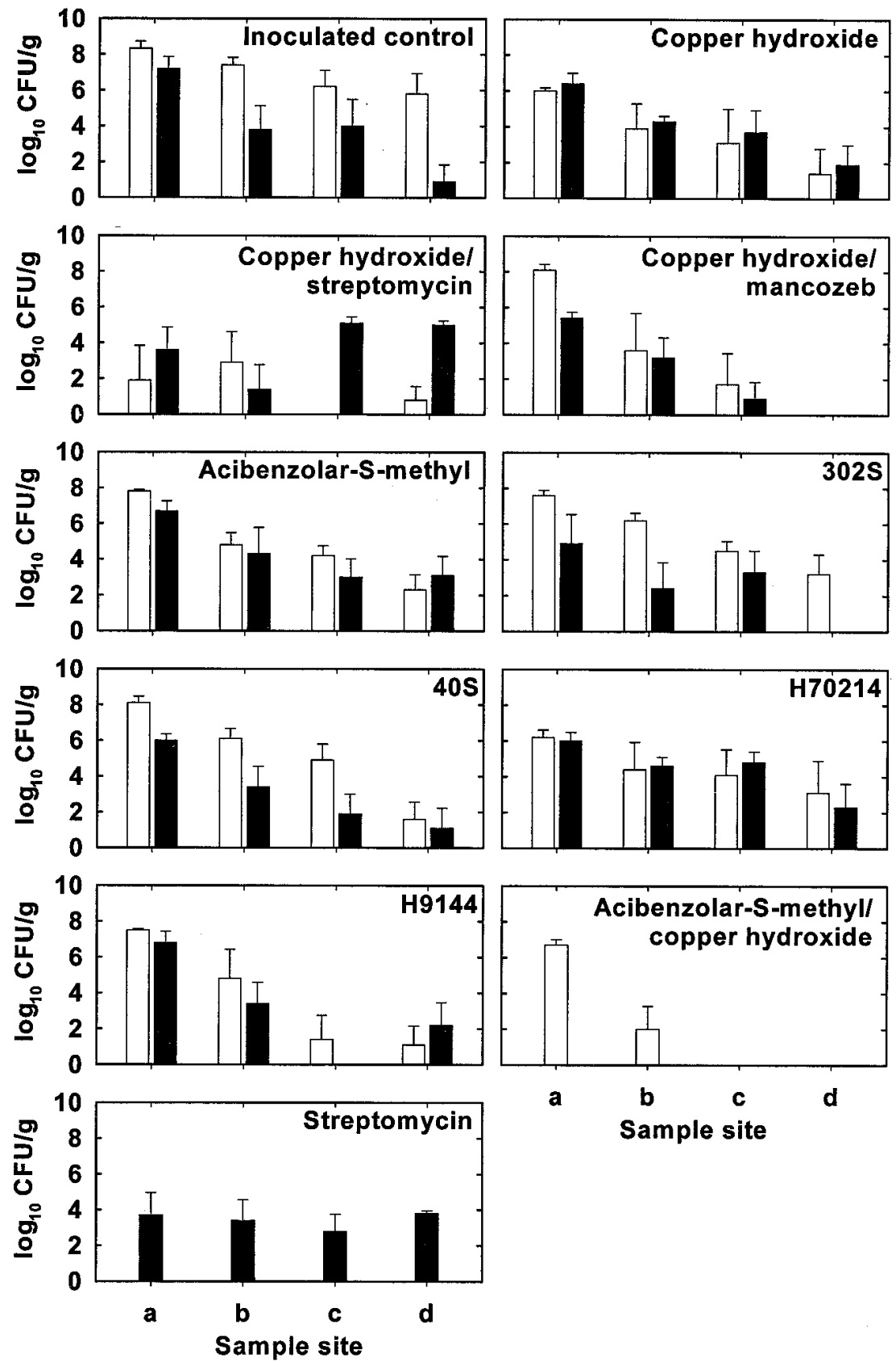

Fig. 2. Populations of Clavibacter michiganensis subsp. michiganensis (CFU/g) on treated or untreated tomato seedlings in the greenhouse prior to transplanting in the field in 1996 ( $\square$ ) and 1997 (ם) when sampled from sites adjacent to the focus of $C$. michiganensis subsp. michiganensis inoculation (a), the center of the treatment (b, c), and the point farthest from the inoculum focus (d). Vertical bars represent standard error. versus copper hydroxide mixed with mancozeb; (xiii) ABM versus $A B M$ mixed with copper hydroxide (1996 only); (xiv) avirulent strain $40 \mathrm{~S}$ versus avirulent strain 302S. In 1997, similar contrasts were used, except the streptomycin treatment was considered a positive control and used for the following contrasts: (i) untreated, inoculated susceptible and resistant cultivars, and streptomycin treatment versus untreated, uninoculated susceptible and resistant cultivars; (ii) untreated, inoculated or uninoculated resistant cultivars, and streptomycin treatment versus all other treatments; (iii) streptomycin versus inoculated resistant cultivars. ABM mixed with copper hydroxide was not included in contrasts for 1997 because it was not a treatment in that year.

\section{RESULTS}

Impact of treatments on pathogen populations and spread among transplants in the greenhouse. Symptoms on seedlings that were directly inoculated with bacteria and introduced into the treatment flats included cankers, firing of leaves, wilt, and death. Populations of C. michiganensis subsp. michiganensis were detected prior to transplanting in the field in all inoculated treatments, but not in the uninoculated treatments each year. Pathogen populations differed significantly from the untreated, inoculated susceptible cultivar in 1996 and 1998, but not $1997(P=$ 0.333; Fig. 2).

In 1996, all treatments significantly $(P<$ $0.001)$ limited pathogen populations compared with the untreated, inoculated susceptible cultivar (Table 1, Fig. 2). The populations of $C$. michiganensis subsp. michiganensis on inoculated susceptible plants treated with fungicides, $\mathrm{ABM}$, or ABM mixed with copper hydroxide were the same as on the inoculated resistant cultivars $(P=0.504)$. Copper hydroxide alone or mixed with mancozeb or streptomycin significantly limited pathogen populations compared with treatment with ABM, ABM mixed with copper hydroxide, and the avirulent strains $(P=0.006)$. The addition of streptomycin or mancozeb to copper hydroxide did not alter pathogen populations $(P=0.161)$, but copper hydroxide mixed with streptomycin significantly limited populations compared with copper hydroxide mixed with mancozeb $(P$ $=0.053$ ). Adding copper hydroxide to ABM significantly limited pathogen populations $(P=0.013)$ compared with $\mathrm{ABM}$ alone. ABM alone or mixed with copper hydroxide limited pathogen populations compared with the avirulent strain treatments $(P=0.014)$. Pathogen populations were not different between the two avirulent strains $(P=0.844)$.

In 1998, treatments significantly $(P<$ 0.001 ) limited pathogen populations compared with the untreated, susceptible cultivar (Table 1, Fig. 3). Copper hydroxide alone $(P<0.001)$, copper hydroxide mixed 
with mancozeb $(P<0.001)$, ABM $(P<$ $0.001)$, and streptomycin $(P<0.001)$ had lower populations than the untreated, inoculated susceptible plants. Adding mancozeb to copper hydroxide did not change pathogen populations compared with copper hydroxide alone $(P=0.265)$. Pathogen populations on plants treated with copper hydroxide were not different from $\mathrm{ABM}$ and streptomycin $(P=0.109)$, and populations on $\mathrm{ABM}$ were not different from streptomycin $(P=0.509)$.

Only in 1997 did the treatments significantly affect pathogen spread $(P=0.001)$. Copper hydroxide mixed with mancozeb limited spread compared with copper hydroxide mixed with streptomycin $(P<$ 0.001 ), but there was no difference in spread on plants treated with copper hydroxide alone and copper hydroxide mixed with mancozeb or streptomycin $(P=$ 0.074). Streptomycin was less effective than the resistant cultivars in limiting pathogen spread $(P=0.004)$.
In 1997, avirulent isolates were detected at site $b$ in 21 of the 36 treatments not initially inoculated with an avirulent strain. At least one sample from every treatment was infested with the avirulent strain except for the copper hydroxide mixed with mancozeb treatment and the untreated, uninoculated susceptible cultivars, which were kept in a separate greenhouse. There was no correlation between the populations of virulent and avirulent strains in these treatments. This lack of correlation could have several causes, including different effects of the treatments on the virulent and avirulent strains, none of which were isogenic, different times of colonization of individual treatments by the avirulent strains, or both. The data collected do not allow us to resolve these issues.

Impact of treatments on yield and development of symptoms in the field. At the time of transplanting, the average bacterial populations on seedlings from greenhouse treatment sites $b$ and $c$ in the un- treated, inoculated susceptible plants that were used to establish field plots (Fig. 1) were $4.1 \times 10^{7}(1996)$ and $6.1 \times 10^{5} \mathrm{CFU} / \mathrm{g}$ of tissue (1997). All treatments limited the average pathogen populations on seedlings of sites $b$ and $c$ to $<8.2 \times 10^{6}$ and $<4.2 \times$ $10^{5} \mathrm{CFU} / \mathrm{g}$ of tissue in 1996 and 1997 , respectively.

Plants showed foliar symptoms of bacterial canker, including necrosis of the outer leaf edges, or "firing," and brown to tan lesions on peduncles at the end of the growing season. Final foliar populations ranged from $9.3 \times 10^{7}$ to $1.8 \times 10^{9}$ and 1.4 $\times 10^{7}$ to $3.9 \times 10^{8} \mathrm{CFU} / \mathrm{g}$ of tissue in 1996 and 1997, respectively. The untreated, uninoculated susceptible plants, which received field applications of streptomycin in 1996 and 1997, had populations of $7.1 \times$ $10^{5}$ to $9.1 \times 10^{6}$ and $1.7 \times 10^{7}$ to $3.6 \times 10^{7}$ CFU/g of tissue in 1996 and 1997, respectively.

In 1996, fewer plants survived in the untreated, inoculated susceptible cultivar $(9.5$

Table 1. Populations of Clavibacter michiganensis subsp. michiganensis on greenhouse tomato seedlings and summary of contrasts on pathogen populations comparing treatments applied to inoculated tomato seedlings in the greenhouse in 1996 and 1998

\begin{tabular}{|c|c|c|c|c|c|c|c|c|c|}
\hline \multirow[b]{3}{*}{ Treatment $^{\mathrm{b}}$} & \multicolumn{9}{|c|}{ C. michiganensis subsp. michiganensis (CFU/g of tissue) ${ }^{\mathrm{a}}$} \\
\hline & \multicolumn{4}{|c|}{1996} & \multicolumn{5}{|c|}{1998} \\
\hline & Site a & Site b & Site c & Site d & Site a & Site b & Site c & Site d & Site e \\
\hline $\begin{array}{l}\text { Untreated, inoculated susceptible } \\
\text { cultivar }\end{array}$ & $3.8 \times 10^{8}$ & $5.4 \times 10^{7}$ & $2.9 \times 10^{7}$ & $9.6 \times 10^{6}$ & $9.6 \times 10^{7 \mathrm{c}}$ & $5.7 \times 10^{6}$ & $8.2 \times 10^{4}$ & $1.4 \times 10^{5}$ & $1.7 \times 10^{7}$ \\
\hline Copper hydroxide & $1.3 \times 10^{6}$ & $5.8 \times 10^{5}$ & $1.5 \times 10^{7}$ & $9.5 \times 10^{4}$ & $2.3 \times 10^{2}$ & $0^{\mathrm{d}}$ & 0 & 0 & 0 \\
\hline $\begin{array}{l}\text { Copper hydroxide mixed with } \\
\text { mancozeb }\end{array}$ & $2.2 \times 10^{8}$ & $1.4 \times 10^{7}$ & $2.4 \times 10^{6}$ & 0 & $7.7 \times 10^{5}$ & 0 & 0 & 0 & 0 \\
\hline $\begin{array}{l}\text { Copper hydroxide mixed with } \\
\text { streptomycin }\end{array}$ & $1.5 \times 10^{7}$ & $9.3 \times 10^{5}$ & 0 & 0 & $\ldots \mathrm{e}$ & $\ldots$ & $\cdots$ & $\cdots$ & $\cdots$ \\
\hline Streptomycin & $\ldots$ & $\ldots$ & $\ldots$ & $\ldots$ & $1.7 \times 10^{5}$ & $7.5 \times 10^{1}$ & 0 & 0 & $1.7 \times 10^{4}$ \\
\hline Acibenzolar-S-methyl & $6.3 \times 10^{7}$ & $4.9 \times 10^{5}$ & $1.3 \times 10^{4}$ & $2.4 \times 10^{3}$ & $3.9 \times 10^{6}$ & $2.3 \times 10^{4}$ & 0 & 0 & $9.2 \times 10^{3}$ \\
\hline $\begin{array}{l}\text { Acibenzolar-S-methyl mixed with } \\
\text { copper hydroxide }\end{array}$ & $9.0 \times 10^{6}$ & $5.8 \times 10^{4}$ & 0 & 0 & 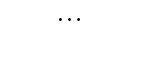 & & 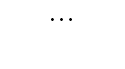 & 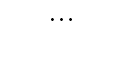 & . \\
\hline Avirulent strain $302 \mathrm{~S}$ & $7.4 \times 10^{7}$ & $4.3 \times 10^{6}$ & $1.9 \times 10^{5}$ & $2.1 \times 10^{4}$ & $\cdots$ & $\cdots$ & $\cdots$ & $\cdots$ & $\cdots$ \\
\hline Avirulent strain $40 \mathrm{~S}$ & $3.1 \times 10^{8}$ & $7.4 \times 10^{6}$ & $6.2 \times 10^{6}$ & $1.1 \times 10^{3}$ & $\ldots$ & $\ldots$ & $\ldots$ & $\ldots$ & $\ldots$ \\
\hline Inoculated resistant cultivar $\mathrm{H} 70214$ & $4.1 \times 10^{6}$ & $1.8 \times 10^{6}$ & $1.1 \times 10^{6}$ & $1.5 \times 10^{6}$ & $\ldots$ & $\ldots$ & $\ldots$ & $\ldots$ & $\ldots$ \\
\hline Inoculated resistant cultivar H9144 & $3.4 \times 10^{7}$ & $3.3 \times 10^{6}$ & $6.5 \times 10^{4}$ & $4.2 \times 10^{3}$ & $\cdots$ & $\cdots$ & $\cdots$ & $\cdots$ & $\cdots$ \\
\hline \multicolumn{8}{|l|}{1996 Contrast } & $F$ value & $P$ value \\
\hline \multirow{2}{*}{\multicolumn{8}{|c|}{ Untreated, inoculated susceptible cultivar vs. all other treatments }} & 18.37 & $<0.001 * \mathrm{f}$ \\
\hline & & & & & & & & 0.46 & 0.504 \\
\hline \multicolumn{8}{|c|}{$\begin{array}{l}\text { Copper hydroxide alone or mixed with streptomycin or mancozeb vs. acibenzolar- } S \text {-methyl, acibenzolar- } S \text {-methyl mixed with } \\
\text { copper hydroxide, and avirulent strain treatments }\end{array}$} & 8.95 & $0.006^{*}$ \\
\hline \multicolumn{8}{|c|}{ Copper hydroxide alone vs. copper hydroxide mixed with streptomycin or mancozeb } & 2.07 & 0.161 \\
\hline \multicolumn{8}{|c|}{ Copper hydroxide mixed with streptomycin vs. copper hydroxide mixed with mancozeb } & 3.98 & $0.053 *$ \\
\hline \multicolumn{8}{|c|}{ Acibenzolar-S-methyl vs. acibenzolar- $S$-methyl mixed with copper hydroxide } & 7.03 & $0.013 *$ \\
\hline \multicolumn{8}{|c|}{ Acibenzolar- $S$-methyl, acibenzolar- $S$-methyl mixed with copper hydroxide vs. avirulent strain treatments } & 6.74 & $0.014 *$ \\
\hline \multicolumn{8}{|c|}{ Avirulent strain $40 \mathrm{~S}$ vs. avirulent strain $302 \mathrm{~S}$} & 0.04 & 0.844 \\
\hline \multicolumn{10}{|l|}{1998 Contrast } \\
\hline \multicolumn{8}{|c|}{ Untreated, inoculated susceptible cultivar vs. all other treatments } & 17.27 & $<0.001 *$ \\
\hline \multicolumn{8}{|c|}{ Copper hydroxide alone or mixed with mancozeb vs. untreated, inoculated susceptible cultivar } & 74.95 & $<0.001 *$ \\
\hline \multicolumn{8}{|c|}{ Copper hydroxide vs. copper hydroxide mixed with mancozeb } & 1.31 & 0.265 \\
\hline \multicolumn{8}{|c|}{ Acibenzolar-S-methyl vs. untreated, inoculated susceptible cultivar } & 30.88 & $<0.001 *$ \\
\hline \multicolumn{8}{|c|}{ Streptomycin vs. untreated, inoculated susceptible cultivar } & 37.07 & $<0.001 *$ \\
\hline \multicolumn{8}{|c|}{ Copper hydroxide vs. acibenzolar- $S$-methyl and streptomycin } & 2.81 & 0.109 \\
\hline \multicolumn{8}{|l|}{ Acibenzolar- $S$-methyl vs. streptomycin } & 0.45 & 0.509 \\
\hline
\end{tabular}

${ }^{a}$ Average bacterial populations at treatment sites b and c (1996) or site c (1998).

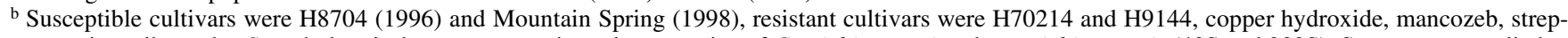
tomycin, acibenzolar-S-methyl, avirulent streptomycin-resistant strains of $C$. michiganensis subsp. michiganensis (40S and 302S). Sprays were applied at 5-day intervals for a total of five and nine applications in 1996 and 1998, respectively.

${ }^{\mathrm{c}}$ Means of bacterial populations at site c of 12 untreated, inoculated treatments (1998).

${ }^{\mathrm{d}}$ A zero indicates a population below detectable levels.

e Treatment was not included in that year.

f * Indicates the contrast is significant at $P \leq 0.05$ (1996) or $P \leq 0.008$ (1998). 
out of a maximum of 12) compared with the other treatments $(\geq 11.0)(P=0.005)$. In 1997 , plant survival in the untreated, inoculated susceptible cultivar ( 8 out of a maximum of 12) was not different from the other treatments (7.3 to 10.3 plants) $(P=$ 0.411).

Untreated, inoculated susceptible plants produced yields that were 61 and $93 \%$ (Table 2) of those produced by the untreated, uninoculated susceptible plants in 1996 and 1997, respectively. In 1996, the yield from the untreated, inoculated susceptible plants was significantly reduced compared with the other treatments included in this study $(P=0.021)$. In 1997 , the yield from the untreated, inoculated susceptible plants was not different from the other treatments $(P=0.457)$, and the yield from plants treated with copper hydroxide alone was significantly reduced compared with copper hydroxide mixed with streptomycin or mancozeb $(P=$ 0.005 ). The yields of the resistant cultivars (inoculated and uninoculated) were significantly less than the other treatments in $1996(P=0.019)$, but not in $1997(P=$ $0.184)$. The yield of the inoculated resistant plants was significantly less $(P=$ $0.021)$ in 1996 and significantly greater $(P$
$=0.038)$ in 1997 than all other treatments.

The number of fruit with spots was much lower in $1996(\leq 2.8 \%)$ than in 1997 $(\leq 47.9 \%)$ (Table 3). In 1996, there were no diseased fruits in the untreated, uninoculated susceptible and resistant plants compared with $\leq 1.6 \%$ when these cultivars were inoculated. In most treatments, $<1 \%$ of the fruit were diseased in 1996. In 1997, the overall incidence of fruit with spots was $\leq 47.9 \%$. Incidence of fruit with spots was $30.8 \%$ versus $\leq 16.2 \%$ in the untreated, inoculated susceptible and resistant plants, respectively. In untreated, uninoculated susceptible and resistant plants, the incidence of fruit with spots was $\leq 8.9 \%$. While fruit treated with copper hydroxide had $47.9 \%$ of the fruit spotted, the incidence of fruit spotting in the other treatments was 11.7 to $22.4 \%$.

\section{DISCUSSION}

Treatments significantly limited populations of $C$. michiganensis subsp. michiganensis among tomato seedlings in the greenhouse compared with the untreated, uninoculated susceptible cultivar in 1996 and 1998. In 1996 only, the conventional bactericides, including copper hydroxide alone or mixed with mancozeb or strepto-
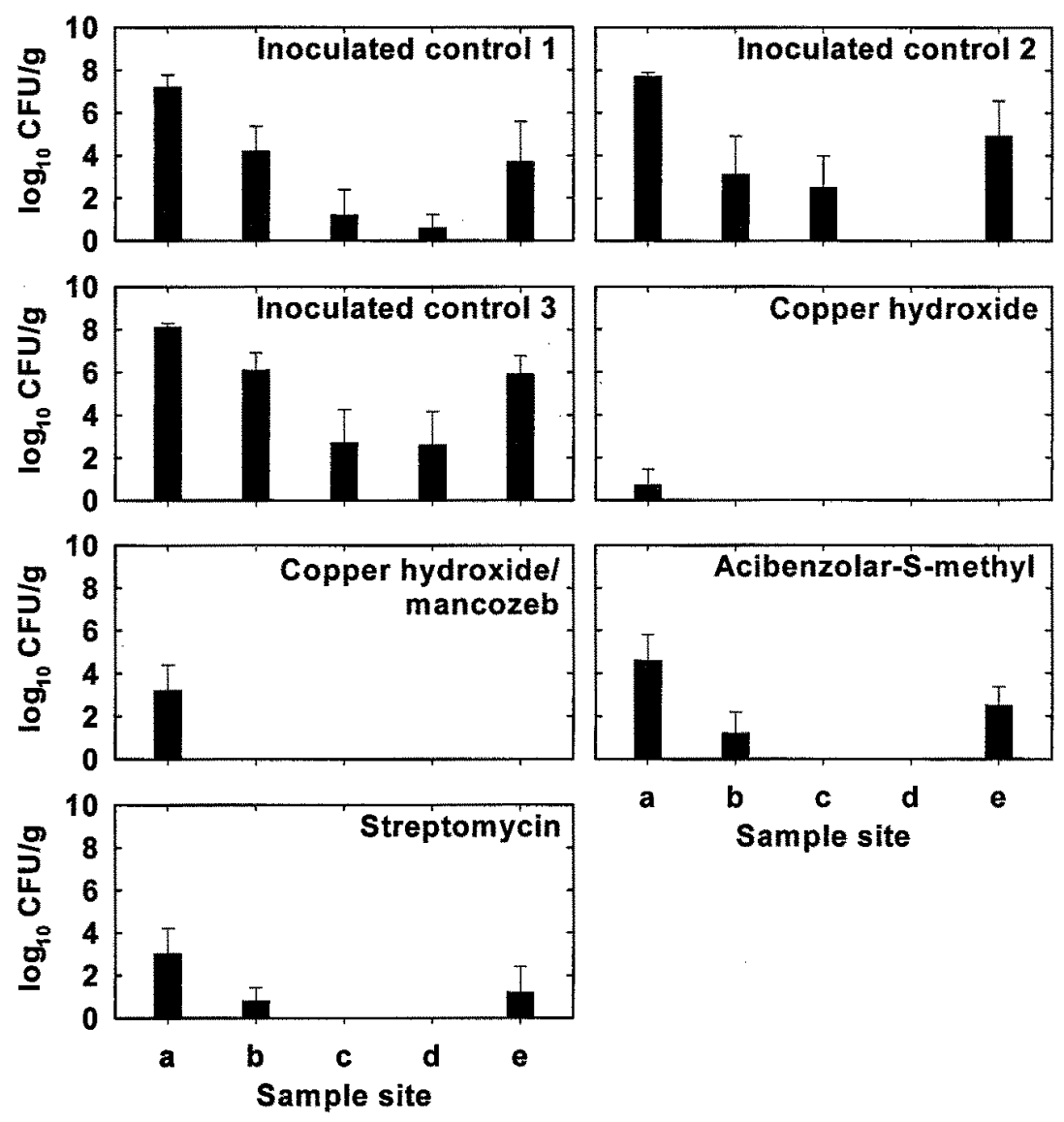

Fig. 3. Populations of Clavibacter michiganensis subsp. michiganensis (CFU/g) on treated or untreated susceptible tomato seedlings in the greenhouse prior to transplanting in the field in 1998 when sampled from sites adjacent to the foci of $C$. michiganensis subsp. michiganensis inoculation (a, e), the center of the treatment (c), and the points in between (b, d). Vertical bars represent standard error. mycin, limited pathogen populations among seedlings in the greenhouse compared with $A B M$ alone or mixed with copper hydroxide. Adding copper hydroxide to ABM significantly limited pathogen populations compared with $\mathrm{ABM}$ alone. $\mathrm{ABM}$ alone or mixed with copper hydroxide was more effective than the avirulent strains of C. michiganensis subsp. michiganensis. Streptomycin was included in our trial as a standard, but cannot be recommended for use in Michigan because the label does not permit greenhouse application. In our study, adding mancozeb to copper hydroxide did not limit pathogen spread in the greenhouse, as suggested in a previous study (11). Copper hydroxide mixed with mancozeb has been shown to enhance control of bacterial diseases and limit epiphytic bacterial populations compared with using copper alone $(12,17)$.

Results from this study indicate that cultivar resistance and ABM may be helpful in disease management, especially when utilized with copper. Other studies have also shown positive results with ABM for management of bacterial diseases. In a field study, ABM provided better control of bacterial spot (Xanthomonas campestris pv. vesicatoria) (15) and bacterial speck (Pseudomonas syringae pv. tomato) (16) on tomato than copper hydroxide mixed with maneb or mancozeb, respectively. In a greenhouse study with tobacco, ABM alone or mixed with copper oxychloride was more effective than copper oxychloride alone in reducing chlorosis and necrosis caused by Pseudomonas syringae pv. tabaci tox + (2). In tobacco fields, disease symptoms were limited when seedlings were treated with copper oxychloride only in the seed bed $(9.3 \%)$, or treated with ABM alone $(2.7 \%)$ or in combination with copper oxychloride in the seed bed and once in the field $(4.7 \%)$, compared with the untreated control (72\%) (2). Cole (2) reported mild phytotoxicity on tobacco from the application of ABM. In our study, a decrease in the establishment of transplants in the field was observed among seedlings treated in the greenhouse with ABM at 5day intervals.

A population of $C$. michiganensis subsp. michiganensis of $10^{7} \mathrm{CFU} / \mathrm{g}$ of tissue or higher occurred on the untreated, inoculated susceptible seedlings at the end of the greenhouse growing cycle (just prior to planting in the field) in 1996 and was associated with development of severe disease symptoms in the field. A previous study indicated that susceptible seedlings with populations of $C$. michiganensis subsp. michiganensis of $10^{7} \mathrm{CFU} / \mathrm{g}$ of tissue or higher were associated with symptoms in the field including plant stunting, yield loss, and death (11). In 1996, yields from the resistant cultivars were significantly reduced compared with the other treatments regardless of inoculation. These plants did not exhibit significant disease 
symptoms, and the pathogen population did not exceed the $10^{7} \mathrm{CFU} / \mathrm{g}$ of tissue threshold. The resistant cultivars used were late maturing and may have been negatively affected by the shortened growing season in 1996 (66 days) compared with 1997 (99 days).

In 1997, pathogen populations at the end of the greenhouse growing cycle did not exceed $6.1 \times 10^{5} \mathrm{CFU} / \mathrm{g}$ of tissue, even in the untreated, inoculated susceptible seedlings, and yield losses in the field were not observed among treatments. This research verifies that transplants placed in the field with low pathogen populations will produce commercially acceptable yields under Michigan growing conditions. One exception occurred in 1997; one of the four blocks of the copper hydroxide treatment had a very low plant stand count (3 out of 12 plants) in the field shortly after transplanting due to unfavorable field condi- tions. This likely contributed to the observed reduced yield.

Final foliar field populations at the end of the growing seasons ranged from $1.4 \times$ $10^{7}$ to $1.8 \times 10^{9} \mathrm{CFU} / \mathrm{g}$ of tissue. The untreated, uninoculated plants had lower pathogen populations $\left(4.2 \times 10^{4}\right.$ to $3.6 \times$ $10^{7} \mathrm{CFU} / \mathrm{g}$ of tissue). All treatments, including the untreated, uninoculated plants, exhibited leaf margin necrosis. Chang et al. (1) determined that leaf surface populations of $C$. michiganensis subsp. michiganensis at $10^{7}$ to $10^{9} \mathrm{CFU} / \mathrm{g}$ fresh weight can occur at least $2.7 \mathrm{~m}$ from the focus of infection, resulting in secondary spread and relatively minor disease symptom development. The field populations observed in our study exceeded the leaf surface population of $C$. michiganensis subsp. michiganensis that Chang et al. (1) determined was necessary before symptoms of secondary infection occur, including spotted fruit and firing of leaflets. In Michigan, bacterial canker symptoms, such as necrosis of the leaf margin, occur in mid to late season, but are seldom associated with economically significant losses $(20,21)$.

"Bird's-eye" fruit spotting occurred regardless of treatment, including the uninoculated plants that received field applications of streptomycin, indicating that pathogen spread occurred within the field. Generally, bird's-eye spotting does not affect quality of processing tomatoes grown for paste, but does affect tomatoes processed for whole pack (21) and tomatoes grown for the fresh market. Research on the epidemiology of fruit spot formation is lacking, but it is known that bird's eye spots are a result of flower (18) and young fruit infection (6). A recent study found that flowers inoculated two days postanthesis were most susceptible to infection (18). In addition, small green fruit devel-

Table 2. Fruit yield and summary of contrasts on fruit yield comparing treatments applied to tomato seedlings in the greenhouse that were not inoculated or inoculated with Clavibacter michiganensis subsp. michiganensis in 1996 and 1997

\begin{tabular}{|c|c|c|c|c|}
\hline \multirow[b]{2}{*}{ Treatment $^{\mathrm{a}}$} & \multicolumn{4}{|c|}{ Yield (kg/5 plants) } \\
\hline & \multicolumn{2}{|c|}{1996} & \multicolumn{2}{|c|}{1997} \\
\hline Untreated, uninoculated susceptible cultivarb & \multicolumn{2}{|c|}{9.5} & \multicolumn{2}{|c|}{17.6} \\
\hline Untreated, inoculated susceptible cultivar & \multicolumn{2}{|c|}{5.8} & \multicolumn{2}{|c|}{16.4} \\
\hline Copper hydroxide & \multicolumn{2}{|c|}{9.3} & \multicolumn{2}{|c|}{11.6} \\
\hline Copper hydroxide mixed with mancozeb & \multicolumn{2}{|c|}{9.1} & \multicolumn{2}{|c|}{16.0} \\
\hline Copper hydroxide mixed with streptomycin & \multicolumn{2}{|c|}{9.0} & \multicolumn{2}{|c|}{19.1} \\
\hline Streptomycin & \multicolumn{2}{|c|}{$\ldots c$} & \multicolumn{2}{|c|}{20.6} \\
\hline Acibenzolar-S-methyl & \multicolumn{2}{|c|}{8.6} & \multicolumn{2}{|c|}{15.4} \\
\hline Acibenzolar-S-methyl mixed with copper hydroxide & \multicolumn{2}{|c|}{9.4} & \multicolumn{2}{|c|}{$\cdots$} \\
\hline Avirulent strain $302 \mathrm{~S}$ & \multicolumn{2}{|c|}{9.8} & \multicolumn{2}{|c|}{19.1} \\
\hline Avirulent strain $40 \mathrm{~S}$ & \multicolumn{2}{|c|}{8.7} & \multicolumn{2}{|c|}{19.4} \\
\hline Inoculated resistant cultivar $\mathrm{H} 70214$ & \multirow{2}{*}{\multicolumn{2}{|c|}{4.9}} & \multirow{2}{*}{\multicolumn{2}{|c|}{19.8}} \\
\hline Inoculated resistant cultivar $\mathrm{H} 9144$ & \multirow{2}{*}{\multicolumn{2}{|c|}{$\begin{array}{l}8.5 \\
6.8\end{array}$}} & \multirow{2}{*}{\multicolumn{2}{|c|}{17.8}} \\
\hline Uninoculated resistant cultivar $\mathrm{H} 70214^{\mathrm{b}}$ & & & \multirow{2}{*}{\multicolumn{2}{|c|}{$\begin{array}{l}14.9 \\
17.8\end{array}$}} \\
\hline Uninoculated resistant cultivar $\mathrm{H} 9144^{\mathrm{b}}$ & \multicolumn{2}{|c|}{8.3} & & \\
\hline Contrast & $F$ & $P$ & $F$ & $P$ \\
\hline $\begin{array}{l}\text { Untreated, inoculated susceptible and resistant cultivars, and streptomycin treatment (1997 only) } \\
\text { vs. untreated, uninoculated susceptible and resistant cultivars }\end{array}$ & 3.81 & 0.059 & 1.99 & 0.711 \\
\hline Untreated, inoculated and uninoculated susceptible cultivar vs. all other treatments & 1.17 & 0.287 & 0.14 & 0.711 \\
\hline $\begin{array}{l}\text { Inoculated and uninoculated resistant cultivars, and streptomycin treatment (1997 only) vs. all } \\
\text { other treatments }\end{array}$ & 6.02 & $0.019 * \mathrm{~d}$ & 1.84 & 0.184 \\
\hline $\begin{array}{l}\text { Untreated, inoculated susceptible cultivar vs. fungicides, acibenzolar- } S \text {-methyl, acibenzolar- } S \text { - } \\
\text { methyl mixed with copper hydroxide, }{ }^{\text {e }} \text { and avirulent strain treatments }\end{array}$ & 5.82 & 0.021 & 0.57 & 0.457 \\
\hline $\begin{array}{l}\text { Untreated, uninoculated susceptible cultivar vs. fungicides, acibenzolar- } S \text {-methyl, acibenzolar- } S \text { - } \\
\text { methyl mixed with copper hydroxide, and avirulent strain treatments }\end{array}$ & 0.35 & 0.557 & 0.00 & 0.961 \\
\hline $\begin{array}{l}\text { Inoculated resistant cultivars vs. fungicides, acibenzolar- } S \text {-methyl, acibenzolar- } S \text {-methyl mixed } \\
\text { with copper hydroxide, and avirulent strain treatments }\end{array}$ & 5.86 & $0.021 *$ & 4.65 & $0.038^{*}$ \\
\hline $\begin{array}{l}\text { Uninoculated resistant cultivars vs. fungicides, acibenzolar- } S \text {-methyl, acibenzolar- } S \text {-methyl mixed } \\
\text { with copper hydroxide, and avirulent strain treatments }\end{array}$ & 2.00 & 0.166 & 0.46 & 0.503 \\
\hline Interaction between inoculation and no inoculation & 1.86 & 0.181 & 1.60 & 0.213 \\
\hline $\begin{array}{l}\text { Copper hydroxide alone or mixed with streptomycin or mancozeb vs. acibenzolar-S-methyl, aci- } \\
\text { benzolar- } S \text {-methyl mixed with copper hydroxide, and avirulent strain treatments }\end{array}$ & 0.02 & 0.882 & 2.84 & 0.101 \\
\hline $\begin{array}{l}\text { Acibenzolar-S-methyl and acibenzolar- } S \text {-methyl mixed with copper hydroxide vs. avirulent strain } \\
\text { treatments }\end{array}$ & 0.03 & 0.858 & 3.43 & 0.072 \\
\hline Copper hydroxide vs. copper hydroxide mixed with streptomycin or mancozeb & 0.00 & 0.979 & 9.08 & $0.005^{*}$ \\
\hline Copper hydroxide mixed with streptomycin vs. copper hydroxide mixed with mancozeb & 0.00 & 0.964 & 1.33 & 0.256 \\
\hline Acibenzolar- $S$-methyl vs. acibenzolar- $S$-methyl mixed with copper hydroxide & 0.19 & 0.662 & $\ldots$ & $\ldots$ \\
\hline Avirulent strain $40 \mathrm{~S}$ vs. avirulent strain $302 \mathrm{~S}$ & 0.40 & 0.533 & 0.00 & 0.959 \\
\hline Streptomycin vs. inoculated resistant cultivars & $\ldots$ & $\ldots$ & 0.57 & 0.454 \\
\hline
\end{tabular}


Table 3. Incidence of fruit spotting in the field on tomato plants which were grown from seedlings that were inoculated or not inoculated with Clavibacter michiganensis subsp. michiganensis and subjected to spray treatments in the greenhouse in 1996 and 1997

\begin{tabular}{|c|c|c|}
\hline \multirow[b]{2}{*}{ Treatment $^{\mathrm{a}}$} & \multicolumn{2}{|c|}{ Diseased fruit $(\%)^{b}$} \\
\hline & 1996 & 1997 \\
\hline Untreated, uninoculated susceptible cultivar & 0.0 & 8.9 \\
\hline Untreated, inoculated susceptible cultivar & 1.6 & 30.8 \\
\hline Copper hydroxide & 0.2 & 47.9 \\
\hline Copper hydroxide mixed with mancozeb & 2.8 & 22.4 \\
\hline Copper hydroxide mixed with streptomycin & 2.0 & 11.7 \\
\hline Streptomycin & $\ldots \mathrm{c}$ & 17.1 \\
\hline Acibenzolar- $S$-methyl & 0.8 & 20.2 \\
\hline Acibenzolar- $S$-methyl mixed with copper hydroxide & 0.3 & $\cdots$ \\
\hline Avirulent strain $302 \mathrm{~S}$ & 0.0 & 17.2 \\
\hline Avirulent strain $40 \mathrm{~S}$ & 1.8 & 19.1 \\
\hline Inoculated resistant cultivar $\mathrm{H} 70214$ & 0.3 & 16.2 \\
\hline Inoculated resistant cultivar H9144 & 0.6 & 5.3 \\
\hline Uninoculated resistant cultivar $\mathrm{H} 70214^{\mathrm{d}}$ & 0.0 & 7.9 \\
\hline Uninoculated resistant cultivar $\mathrm{H} 9144^{\mathrm{d}}$ & 0.0 & 6.5 \\
\hline
\end{tabular}

a Resistant cultivars H70214 and H9144, copper hydroxide, mancozeb, streptomycin, acibenzolar-Smethyl, avirulent streptomycin-resistant strains $302 \mathrm{~S}$ and $40 \mathrm{~S}$ of C. michiganensis subsp. michiganensis. Sprays were applied every 5 days for a total of five applications in 1996 and 1997.

b By weight.

c Treatment was not included in that particular year.

$\mathrm{d}$ Transplants grown in a separate greenhouse to avoid contamination from inoculated plants.

oped bird's eye lesions when inoculated with C. michiganensis subsp. michiganensis. Similarly, a study by Getz et al. (9) determined that spots on tomato fruit caused by Pseudomonas syringae pv. tomato occurred during the time when flowers were past anthesis and until fruit were a maximum of $3 \mathrm{~cm}$ in diameter. Concurrent scanning electron microscopy studies revealed that the bacterial populations inhabited trichomes prior to anthesis and populated the openings left after the trichomes were shed, indicating that trichomes are the source of infection on fruit (8).

This study verifies findings of Hausbeck et al. (11) that to prevent severe bacterial canker disease in the field, growers should initiate and sustain bactericide applications or other management strategies in the greenhouse to suppress pathogen populations. Oftentimes, treatments are made in response to disease symptoms occurring in the field. By focusing control strategies in the greenhouse rather than in the field, growers may have better control of the pathogen and avoid economic losses resulting from yield losses caused by this disease.

\section{ACKNOWLEDGMENTS}

This study was supported by funding from the Michigan Agricultural Experiment Station, H. J. Heinz Co., Mid-America Processors Association, USDA North Central IPM Program, and Syngenta Crop Protection Inc. Ag. Products. We thank B. Cortright, S. Linderman, C. Medina-Mora, and B. Quackenbush for technical support.

\section{LITERATURE CITED}

1. Chang, R. J., Ries, S. M., and Pataky, J. K. 1992. Local sources of Clavibacter michiganensis ssp. michiganensis in the development of bacterial canker on tomatoes. Phytopathology 82:553-560.

2. Cole, D. L. 1999. The efficacy of acibenzolarS-methyl, an inducer of systemic acquired resistance, against bacterial and fungal diseases of tobacco. Crop Prot. 18:267-273.

3. Conover, W. J. 1980. Practical Nonparametric Statistics, 2nd ed. John Wiley \& Sons, New York.

4. Cooksey, D. A. 1990. Genetics of bactericide resistance in plant pathogenic bacteria. Annu. Rev. Phytopathol. 28:201-219.

5. Dhingra, O. D., and Sinclair, J. B. 1995. Basic Plant Pathology Methods, 2nd ed. CRC Press, Boca Raton, FL. p. 67.

6. Ehrig, F., and Grisbach, E. 1985. Development of birds eye spots on tomato fruitsInvestigations by scanning electron microscopy. Arch. Phytopathol. Pflanzenschutz 21:419-423.

7. Frey, P., Prior, P., Marie, C., Kotoujansky, A., Trigalet-Demery, D., and Trigalet, A. 1994. Hrp-mutants of Pseudomonas solanacerum as potential biocontrol agents of tomato bacterial wilt. Appl. Environ. Microbiol. 60:31753181.

8. Getz, S., Fulbright, D. W., and Stephens, C. T. 1983. Scanning electron microscopy of infection sites and lesion development on tomato fruit infected with Pseudomonas syringae pv. tomato. Phytopathology 73:39-43.

9. Getz, S., Stephens, C. T., and Fulbright, D. W. 1983. Influence of developmental stage on susceptibility of tomato fruit to Pseudomonas syringae pv. tomato. Phytopathology 73:36-38.

10. Hammerschmidt, R., and Becker, J. S. 1997. Acquired resistance to disease in plants. Pages 247-289 in: Horticultural Reviews, vol.
18. J. Janick, ed. John Wiley \& Sons, New York

11. Hausbeck, M. K., Bell, J., Medina-Mora, C., Podolsky, R., and Fulbright, D. W. 2000. Effect of bactericides on population sizes and spread of Clavibacter michiganensis subsp. michiganensis on tomatoes in the greenhouse and on disease development and crop yield in the field. Phytopathology 90:38-44.

12. Jones, J. B., Woltz, S. S., Jones, J. P., and Portier, K. L. 1991. Population dynamics of Xanthomonas campestris pv. vesicatoria on tomato leaflets treated with copper bactericides. Phytopathology 81:714-719.

13. Kessmann, H., Ryals, J., Staub, T., Oostendorp, M., Ahl Goy, P., Hofmann, C., Friedrich, L., Delaney, T., Lawton, K., Weymann, K., Ligon, H., Vernooij, B., and Uknes, S. 1995. CGA 245704: Mode of action of a new plant activator. Int. Plant Prot. Congr., The Hague, The Netherlands, 2-7 July, 1995.

14. Louws, F. J., Bell, J., Medina-Mora, C. M., Smart, C. D., Opgenorth, D., Ishimaru, C. A., Hausbeck, M. K., de Bruijn, F. J., and Fulbright, D. W. 1998. rep-PCR-mediated genomic fingerprinting: A rapid and effective method to identify Clavibacter michiganensis. Phytopathology 88:862-868.

15. Louws, F. J., Ritchie, D. F., Kousik, C. S., Romero, A. M., Pollard, D. W. 1996. Evaluation of the plant-activator CGA-245704 50WG for control of bacterial spot of tomato. Pages 18-19 in: Annu. Tomato Disease Workshop, 12th. Columbus, Ohio.

16. Manley, B. S., Bassi, A. B., Jr., Tally, A. H., Young, T. R., Pyan, L., Coud, G., and Reuss, W. 1997. Actigard (CGA 245704), a novel approach to bacterial spot and bacterial speck control in tomato. Pages 48-49 in: Annu. Tomato Disease Workshop, 13th. Indianapolis, IN.

17. Marco, G. M. 1983. Control of bacterial spot of pepper initiated by strains of Xanthomonas campestris pv. vesicatoria that differ in sensitivity to copper. Plant Dis. 67:779-781.

18. Medina-Mora, C. M., Hausbeck, M. K., and Fulbright, D. W. 2001. Bird's eye lesions of tomato fruit produced by aerosol and direct application of Clavibacter michiganensis subsp. michiganensis. Plant Dis. 85:88-91.

19. Ricker, M. D., Emmatty, D. A., Schott, M. D., and Ozminkowski, R. H. 1995. Heinz tomato varieties resistant to bacterial canker. Pages 37-39 in: Annu. Tomato Disease Workshop, 10th. Windsor, Ontario Canada.

20. Ricker, M. D., and Riedel, R. M. 1988. Economic importance of secondary spread of Clavibacter michiganensis subsp. michiganensis in northern-grown processing tomatoes. (Abstr.) Phytopathology 78:1570.

21. Ricker, M. D., and Riedel, R. M. 1993. Effect of secondary spread of Clavibacter michiganensis subsp. michiganensis on yield of northern processing tomatoes. Plant Dis. 77:364-366.

22. Ruess, W., Kunz, W., Staub, T., Müller, K., Poppinger, N., Speich, J., and Ahl Goy, P. 1995. Plant activator CGA 245704, a new technology for disease management. Int. Plant Prot. Congr., The Hague, The Netherlands, 27 July, 1995.

23. Zar, J. H. 1996. Biostatistical Analysis, 3rd ed. Prentice Hall, Upper Saddle River, NJ. 